\title{
Antibiotikabruk til bekymring
}

Den medisinske utviklingen går raskt, og det er vanskelig å holde seg orientert om hva som er beste behandling og balansere dette mot den farmasøytiske industris markedsføring. I mange land har myndighetene derfor utgitt retningslinjer for behandling av vanlige sykdommer (1). For å kvalitetssikre slike retningslinjer er det strenge kriterier for utarbeiding av disse (2).

De første norske nasjonale retningslinjer for antibiotikabehandling i allmennpraksis ble utgitt $i$ år 2000 og distribuert til alle allmennleger. Fordi resistenssituasjonen i Norge var og er gunstig, anbefales bruk av «gammeldagse» smalspektrede antibiotika (3). Ciprofloksacin, klindamycin og de nye makrolidene leder raskere til resistensutvikling enn penicillinene og er kun anbefalt som reservepreparater.

Myndighetene bruker ofte salgstallsmålinger som grunnlag for sin antibiotikapolitikk. For å få mer detaljert kunnskap er det nødvendig med kliniske undersøkelser av antibiotikabruk i forhold til diagnose. Fagan \& Skotheims undersøkelse av fluorokinolonbruk i sykehjem i dette nummer av Tidsskriftet viser at det er et betydelig større forbruk av ciprofloksacin enn anbefalingene skulle tilsi (4). Kinoloner har mange økologiske bivirkninger og bør forbeholdes alvorlige og kompliserte urinveisinfeksjoner (5). Mange sykehjemsbeboere har grunnsykdommer som kan bidra til infeksjoner og antibiotikabruk. Grunnet multipatologi og atypiske symptombilder kan det være vanskelig å stille en sikker diagnose, og i sykehjemmene er tilgangen på bakteriologiske undersøkelser dårligere enn den er i sykehus. Dette kan føre til over- og feilbehandling med antibiotika, og det gir økt resistens (6).

Hvorvidt retningslinjer kan endre den kliniske praksis, er avhengig av deres validitet og hvordan de blir markedsført og implementert (7). Noen leger kjenner ikke retningslinjene eller er uenig i anbefalingene. Andre kan ha vansker med å endre etablert forskrivningspraksis (8). Pasientenes oppfatning av behandlingen de får kan gå på tvers av retningslinjene, spesielt ved selvlimiterende infeksjoner. Den offentlige innsatsen på dette området har vært lik null.

Effekten av passiv disseminering av trykte retningslinjer er i beste fall beskjeden (7). For at de skal påvirke forskrivningsmønsteret bør det avsettes tid og midler til implementering (9). Den mest effektive måten å påvirke leger på er å la spesielt utdannede veilede forskriveren i dennes eget miljø (10). Dette kalles «academic detailing» og har vært anvendt med hell innen kollegabasert terapiveiledning (KTV), der 450 norske fastleger diskuterte og endret praksis ved forskrivning av antibiotika ved luftveisinfeksjoner (11).

Omtrent $90 \%$ av antibiotikabruken i Norge skjer i allmennpraksis. Til tross for at retningslinjene på området har eksistert i over ti år, øker både den totale antibiotikabruken og bruken av bredspektrede resistensdrivende midler (6). Etter vår mening skyldes dette bl.a. manglende føringer og bevilgninger fra de offentlige myndighetene som utgir retningslinjene.

Ved neste utgivelse av retningslinjene må det avsettes midler til implementering (1). Folkehelseinstituttet kunne f.eks. utarbeide «pakker» med foredrag, bakgrunnstoff etc., med konkrete opplegg for smågruppeundervisning, seminarer og kurser. Kommuneoverleger og smittevernleger bør kunne benyttes i dette arbeidet, slik det gjøres i Sverige. Kurs i antibiotikabruk bør bli obligatorisk for å beholde spesialiteten i allmennmedisin. Tidligere fikk alle leger utdannet utenfor Norge et kurs i antibiotikabruk, men «noen» avskaffet dette, med henvisning til harmonisering med EU-reglene. På grunn av den unike norske resistenssituasjonen må dette kurset reintroduseres. Vi må drive egen forskning, og vi foreslår at man øremerker midler til klinisk antibiotikaforskning. Det bør også lages opplysningskampanjer rettet mot allmennheten. Tiltak for å forbedre antibiotikabruken er kostnadseffektivt. I Frankrike, hvor det er store resistensproblemer, bruker myndighetene milliardbeløp til å påvirke legene og pasientene - for å få ned forbruket av antibiotika.

I den reviderte utgaven fra 2008 ble anbefalingene om bruk av smalspektrede antibiotika videreført (12). Det er et eget kapittel om antibiotika i sykehjem. Målet var å redusere både den totale antibiotikabruken og bruken av bredspektrede antibiotika. Siden verken myndigheter eller farmasøytisk industri utvikler nye antibiotikapreparater, er dette den eneste måten vi kan bevare antibiotika som virksomme legemidler på.

\section{Dag Berild \\ dag.berild@medisin.uio.no \\ Morten Lindbæk}

Dag Berild (f. 1951) er dr.med. og overlege ved Infeksjonsavdelingen ved Oslo universitetssykehus.

Morten Lindbæk (f. 1950) er professor dr.med. Han er ansatt ved Avdeling for allmennmedisin. Universitetet i Oslo, og leder for Antibiotikasenteret for primærmedisin (ASP).

Oppgitte interessekonflikter: Begge forfatterne har innledet et forskningssamarbeid med Mark Fagan og er medforfattere på hans neste artikkel om antibiotika.

\section{Litteratur}

1. Grol R. Success and failure in the implementation of evidence-based guidelines for clinical practice. Med Care 2001; 39 (suppl 2): 46-52.

2. The AGREE Collaboration. Appraisal of guidelines for research \& evaluation (AGREE) instrument 2001. London: St. George's Hospital Medical School, 2001.

3. Usage of antimicrobial agents and occurrence of antibiotic resistence in Norway 2007. Troms $\varnothing / O s l o: ~ N O R M / N O R M-V E T, 2008$ : 1502-2307.

4. Fagan M, Skotheim SB. Fluorokinolonbruk i sykehjem. Tidsskr Nor Legeforen 2010; 130: 2022-4.

5. Simonsen GS. Overvåking og forekomst av antibiotikaresistens I Norge. Tidsskr Nor Legeforen 2009; 129: 623-8.

6. Blix HS, Røed J, Sti MO. Large variation in antibacterial usage among Norwegian nursing homes. Scand J Infect Dis 2007; 39: 536-41.

7. Grimshaw JM, Russel IT. Effect of clinical guidelines on medical practice: a systematic review of rigorous evaluation. Lancet 1993; 342: 1317-22.

8. Cabana MD, Rand CS, Powe NR et al. Why don 't physicians follow clinical practice guidelines? JAMA 1999; 282: 1458-65

9. Gjelstad S, Dalen I, Lindbæk M. GPs ` antibiotic prescription patterns for respiratory tract infections - still room for improvement. Scan J Prim Health Care 2009; 27: 208-15.

10. Arnold SR, Straus SE. Interventions to improve antibiotic prescribing practices in ambulatory care. Cochrane Database Syst Rev 2005; nr. 4. Art. No.: CD003539. DOI: 10.1002/14651858.CD003539.pub2.

11. Gjelstad S, Fetveit A, Straand J et al. Can antibiotic prescriptions in respiratory tract infections be improved? A cluster randomised educational intervention in general practice - the Prescription Peer Academic Detailing (Rx-PAD) Study (NCT00272155). BMC Health Serv Res 2006: 6: 75.

12. Lindbæk M, red. Nasjonale faglige retningslinjer for antibiotikabruk i primærhelsetjenesten. Oslo: Helsedirektoratet, 2008. www.antibiotikasenteret.no (4.10.2010). 